\title{
Human Security: a Need and a Challenge
}

\author{
Besim Kusari \\ PhD Cand. \\ Tirana European University, Albania. \\ besimkusari@gmail.com
}

DOI:10.5901/mjss.2014.v5n19p515

\begin{abstract}
The purpose of this paper is to emphasize the fact that everyone should contribute to the security aspects, that includes individuals, the society and the state. Each one of us want to live without fear from everyday risks and threats which happen in our surrounding. Nevertheless, each one of us should give our contribution to make this happen, with the purpose of protecting our lives in the same scale as we expect from the society and the state to provide that security. The purpose of this link or relationship of interest between the individual and the society is to reciprocally increase the societal and individual security. Thus, people should protect their lives as strongly as they expect from the society/state to do so. From the context of security provided by the society/state, we want to emphasize that the protection of our community from crime is one of the protection functions of the criminal law, while on the other hand the legal security is an element of rule of law. Criminal law is tasked with safeguarding citizens, by protecting human life, bodily integrity, rights and freedoms, honor, authority, equality and safety and security of the citizens. Security at its broader political and legal meaning includes defence measures and activities for protecting from the endangering of the independence and integrity of the country (nation) and the internal constitutional and legal order. Security as a constitutional value and need should defend the public order, the state and its citizens as well as enable unimpeded functioning of the institutions in all of its segments. On the contrary, the lack of trust of citizens in the judiciary impacts every individual member of the society in the form of legal insecurity which leads to self-judgment with all its destructive elements of this phenomenon. The modern concepts of security everyday and more are based on the obligation of states but also of its citizens, to establish the feeling of collective security based on the principle that "whoever lives and acts in a respective country has the right to feel free." Democratic countries while preparing their policies in the security field, as a very essential and sensitive issue in all aspects of life and of special importance worldwide, try to increase the feeling of social, economical and political security of the nation and its institution towards threats and risks, and they do so by among others by preparing documents, strategies and other above mentioned policies.
\end{abstract}

Keywords: Human rights and freedoms, life, risks and threats, legal security, state obligations.

\section{Introduction}

"Man is born free, yet he is everywhere in chains, how did this change come about? I do not know. But how can such a change become legitimate? I believe I can answer this question."

\section{(Jean-Jacques Rousseau)}

Everyone wants to live without fear from daily risks and threats, which occur every day in the whole world. Thus, he wants to live safe and seeks safety not only for his life, but for his loved ones as well. Same people are endangered and threatened by wars every day and even we witness its consequences through media. The lives of others are endangered by the lack of basic food or drinking water; whilst for some other people the risk is sudden as result of terrorism, biochemical poisons, endangering in this way not only the life of an individual but lives of the society as a whole.

These are the risks that threaten humans directly and result is death. On the other hand some people are endangered and threatened indirectly, slowly but unavoidably. Therefore, each one of us should be familiarized with those risks. Nevertheless, in order to fight those risks, the government structures should be familiarized with them as well. Russo supports two views on his thesis - 'the individual' and 'the state', emphasizing that every person has the right to protection from any attack and that people have entrusted all their rights to the society as absolute "power". Pushed from justifications completely driven towards their "touchiness", people give up their individual freedom carrying it to the "political bodies", According to him the society/state has the right to repression (takes over the responsibility for it), by applying punishments 
against the perpetrators of criminal offences. Thus, people need to protect their lives in the same powerful way as they expect the society/government to offer safety to them.

Protection of the society from the criminality, protective role of the criminal justice

Protection of the society from the criminality, protective role of the criminal justice. Within this scope, the priority task of the criminal law is protection of fundamental human rights and freedom, public order and the security of the country(Salihu:2005). Additionally, criminal law is tasked with protection of special legal benefits of people, such as: human life, bodily integrity, rights and freedom, honor, authority, citizen's equality and security (Salihu:2005). The safety of the citizens means the state of being free from danger or threat, the state of feeling free, and free from a sudden danger (oxford dictionary). A state is secure to the extent to which it is not in danger of having to sacrifice core values if it wishes to avoid war and is able, if challenged, to maintain them by victory in such a war (Lippman: 1991). In this context, guaranteeing the human safety and security requires a multilayer approach to address economic security, food security, health and environment security, individual security, societal and political security. This special meaning of human security is categorized as one of the broad definitions and forms the basis for division of the meaning of human security (Collins: 2007).

Human security is understood also as the protection of individuals from the dangers for their physical or psychological safety, their dignity and wellbeing. An environment capable of ensuring human security to its members is an environment which gives the individuals the opportunity to live a stable and self-determined life (Shahrbanou: 2007). The world can never find peace if people are not safe on their day to day lives. And how can the world be in peace, when everyday people are killed, people die starving, people are tortured, imprisoned, displaced or denied health care or education, in the name of security (Williams:2013). Security related topics on security are subject of modern societies worldwide: they fill the speeches of politicians and experts; newspaper articles and radios are filled with those; and the images of security and insecurity pass through our screens and internet almost constantly (Williams:2013). All this makes security an amazing topic, often deadly, but always very important topic (Williams:2013). In his search for the meaning of life and happiness, every human shall have the opportunity to develop itself according to his or her talent and capabilities (Grabov:2008). The free development of human personality is possible only within the community. The relationship between the individual and the community is that of reciprocal enrichment. The individual may reach full development of his identity in relation to other persons. The community depends on free individual personalities with the belief for his development and potential. This is the characteristics of the society with equal chances for all. Each individual in it has the opportunity of completely expressing his creation and novation. This free personal development in the society of opportunities ensures also societal cohesion (Grabov:2008). The protection of the right to property, enables security of the legal-property relations, protection of property rights from thefts, vandalism and other forms of obtaining property rights and any other forms of removal of individual's property right (Abazoviq:2006).

\section{Legal Security, an element of state of law}

The principle of legal security is also a very important element of the state of law. The precision, clarity and overall stability of legal order of a certain state are considered as its principle formal standards. Nevertheless, the non-violation of the rights gained and the legal expectation that guarantee the applicable norms are considered as the principle standards in the material meaning. In other words, it is required that not only the specific norms, but the entire legal order is understandable, predictable and non-contradictory. In this way, it is believed that this creates the belief of the citizens in the stability of this order and their determination for the need to respect and implement the same on day-to-day life. At the same time, on this basis, the citizens determine also the scope of freedom or their conduct in the state and society (Degenhart: 1998).

The doctrine of the Constitutional Law has accepted that the legal security is one of the key elements of the state of law (Zaganjori:2011). This security means among others also the trust of the citizens in the state and the no amendment of the law for the relations already regulated. The trust has to do with the fact that the citizen should not continuously worry about the amendments and the negative consequences of the normative acts which violate and worsen the situations regulated by previous acts (Zaganjori:2011). Affirming the legal security principle and its main elements, the Constitutional Court of Republic of Albania emphasizes that this principle cannot prevail in every case (Zaganjori:2011). This means that if a legal regulation of an issue is directly affected by a public interest, with all its fundamental elements, this interest will naturally have priority over the principle of legal security. But in this case, it is not about just any consequence, but for fundamental consequences, since the new provision creates a conceptual change on the relationship state- lesser, a change that brings very important consequences (Zaganjori:2011). 


\section{Security, a Constitutional value}

Security as constitutional value and need should ensure protection of public order, protection of the state and its citizens and the unimpeded functioning of the institutions in all its segments. From the definitions quoted, it results that each society, independent from its societal form, is faced with various potential and real dangers, caused by circumstances that may put in question the necessary functioning of certain segments of the society. In this sense, the security should express the ability and respective protection measures of confronting and eliminating the occurrences that destroy the stability of social development of the state and society (Zaganjori:2011). In this parallel, it is important to have the trust of the public in the judiciary, which is a vital element for the aspiration of building the state of law. The lack of trust in the judiciary it affects each individual member of the society in the form of lack of legal security, which leads to self-justice with all the destructive consequences of this (Albanian Union of Judges: 2012). Various subjects and bodies are engaged in protecting certain values and goods and each of them applies specific methods and measures such as: legislative actions, repressive measures etc.

\section{Conclusion}

Every individual needs to consume his safety for his own life and the life of his family, but not only that. Therefore, since the individuals have the need to consume security they are called upon first to contribute to the increase of the level of security, in their families, in their neighborhoods, in their society and up to the state level. Every individual needs protection of their personal rights, their property, and their political rights from any criminal abuse. Security does not exist if we are unable to enjoy it; and we can enjoy it only if the law is respected by each one of us. Individual freedom, personal security and public order are closely linked notions, since there exists a mutual link according to which there is no individual freedom without the personal security, no personal security without public order, there is no individual freedom without public order.

State institutions established to offer security for the citizens, are more and more having difficulties not only in terms of overall security of the communities but for individual security as well. In this context while the U.S. has continuous security problems, Balkan countries cannot remain comfortable towards the occurrences which endanger the lives and wellbeing of citizens. Logically a question is raised!. Can any country through its mechanisms of violence guarantee the safety without the assistance of its citizens? We would categorically say "No" for many reasons. One of the reasons is that even though the legal norms are in force, the law enforcement cannot be everywhere at any given moment to maintain safety and security for its citizens. It is the citizens who should reflect on their assistance to government institutions and to change their approach in terms of the cooperation between the individuals and other people in the neighborhood. The cooperation is implemented through planned phases, because if we fail to plan then we have planned to fail.

\section{Reference}

Abazoviq, Mirsad, (2006), National Security, published by AAB University, Pristina.

Abazoviq, Mirsad, 2006, "National Security", Pristina, pg.17.

Albania Union of Judges, (2012), Judicial Reform as one of 12 priorities of the challenge of integration of Albania to EU: Conference Report and Conclusions, USAID and SOROS, Tirana.

Collins, Alan, (2007),Contemporary security studies, Oxford press university, New York, pg.129.

Degenhart, C., Staatsrecht I., (1998), State Law I. state objectives, state organs, state functions, published by CF Muller Verlag, Germany.

Grabov, Karsten, (2008), Material for civic education and international cooperation, Konrad Adenauer Foundation, Berlin. Jean-Jacques Rousseau, (1968), Social Contract, Penguin group, London.

Oxford Dictionary: http://oxforddictionaries.com/definition/english/security.

Salihu, Ismet, (2005), Criminal Law: General Part, Pristina University, pg 28.

Shahrbanou, Tadjbakhsh and Anuradha, M.Chenoy, (2007), Human security: concepts and implications, Taylor \& Francis Group, New York.

Walter Lippman (1991), cited in Barry Buzan "People, State and Fear" (Hemel Hemptead: Harvester Wheatsheaf, pg.16. Williams, Paul D, (2013), Security studies: An Introduction, 2 ed., Routledge, published in the U.S. and Canada.

Zaganjori, Xh., Anastasi, A., Çani, E,(2011) State of Law on the Constitution of Republic of Albania, (Shteti i së Drejtës në Kushtetutën e Republikës së Shqipërisë), Adelprint, Tirana. 